\title{
Influence of Rice Husk Ash and Fly Ash on Properties of Red Clay
}

\author{
M. S. Sultana ${ }^{1}$, M. I. Hossain ${ }^{1}$, M, A. Rahman ${ }^{1}$, and M. H. Khan ${ }^{2}$ \\ ${ }^{1}$ Institute of Mining, Mineralogy and Metallurgy, BCSIR, Science laboratory Road, Khonjonpur, \\ Joypurhat-5900, Bangladesh \\ ${ }^{2}$ Department of Materials and Metallurgical Engineering, BUET, Dhaka-Bangladesh
}

Received 18 June 2013, accepted in final revised form 28 July 2014

\begin{abstract}
Effects of rice husk ash and fly ash on properties of red clay collected from Naogaon district of Bangladesh were investigated. Different percentages of rice husk ash (RHA) and fly ash $(5 \%, 10 \%$ and $15 \%)$ were thoroughly mixed with clay to analyse various physical and chemical properties of clay followed by heat treatment of $800^{\circ} \mathrm{C}$ to $1100^{\circ} \mathrm{C}$. The samples were tested for compressive strength, linear shrinkage, water absorption, porosity and bulk density. XRD analysis indicates the clay sample was mainly illite type. Water absorption and porosity increased with increasing percentage of ashes. The percentage of water absorption was within 6 to $10 \%$ for different mixture which may be suitable for ceramic and tiles purposes. Both fly ash and RHA of $15 \%$ could be used to improve some properties of clay. The optimum firing temperature for all the samples was $1050^{\circ} \mathrm{C}$. XRD pattern of clay with fly ash and rice husk ash heated at $1050^{\circ} \mathrm{C}$ confirms the presence of feldspar and quartz as major phase and hematite $\left(\mathrm{Fe}_{2} \mathrm{O}_{3}\right)$ and cristobalite phase as minor phase. This red clay deposits reinforced with different appropriate quantities of rice husk ash and fly ash could be used for various low temperature applications in industry and construction purposes.
\end{abstract}

Keywords: Red clay; Rice husk ash; Fly ash; Water absorption; Shrinkage

๑) 2014 JSR Publications. ISSN: 2070-0237 (Print); 2070-0245 (Online). All rights reserved. doi: http://dx.doi.org/10.3329/jsr.v6i3.15343 J. Sci. Res. 6 (3), 421-430 (2014)

\section{Introduction}

Clays are used as raw materials in many industrial fields (ceramics, paper, paint, petroleum industry, catalysis etc). The suitability of clays in industry depends mainly on their characteristics such as mineralogy, chemistry, and plasticity as well as the firing conditions: temperature, soaking time, heating rate and atmosphere.

To assess clay suitability for manufacturing bricks or roofing, floor and wall tiles, clay's technological properties are related with their mineralogical composition, physical

Corresponding author: shammiswe@yahoo.com 
properties, and with their relative proportions. Various physical properties such as shrinkage, water absorption, bulk density, mechanical strength etc acts as the quality control parameters. To produce good quality construction material various additives have been used by different researchers such as rice husk, rice husk ash and saw dust [1-3].

Fly ash is a by-product of thermal power plants resulting from the combustion of pulverized coal in the coal fired furnaces. The chemistry of fly ash enables its use as raw material for ceramic industry as a part replacement of traditional clay. The potential of fly ash as a raw material for ceramic applications was reviewed by Sen et al. [4]. Several authors [5] have studied the effect of fly ash addition on the conventional tile properties and reported its suitability. Effect of partial substitution of clay by fly ash in porcelain compositions has been studied [5, 6].

Several researchers [7] have studied possible ways of making rice husk for block moulding and building construction. These studies were based on the growing cost of lime and cement, traditional stabilizing agents, coupled with the need for the economic utilization of industrial and agricultural wastes for beneficial engineering purposes.

Rice husk ash (RHA) is obtained from the burning of rice husk. The husk is a byproduct of the rice-milling industry. By weight, $10 \%$ of the rice grain is rice husk. On burning the rice husk about $20 \%$ becomes RHA [8]. Several researchers have studied possible ways of making rice husk ash for block moulding and building construction. Rahman [1] investigated properties of clay-sand-mixes different percentages of RHA and burnt at $1000^{\circ} \mathrm{C}$ for 2,4 and 6 hours. He obtained lightweight brick with optimum firing duration of $4 \mathrm{~h}$ and used in load bearing walls. Tonnayopas et al., [9] investigated properties of the clay bricks produced by adding different percentage of RHA and up to $30 \%$ RHA addition was found to meet Thai industrial standard.

The main objective of this study is the best understanding of red clays of northern region of Bangladesh, composition, mineralogy, texture, it can utilize in several industries. The clay deposits of Northern regions are mainly used in the brick manufacturing industries and in the foundries. Manufacturing of brick at high temperature not only create air pollution, but also a highly energy sensitive process. This work will also give a solution of the high temperature, high energy and problem of dumping rice husk ash and fly ash.

\section{Materials and Methods}

\subsection{Materials}

The clay samples were collected from Shibrampur, Dhamurhat upazilla, Naogaon district (location- $25^{\circ} 09 \mathrm{~N}$ and $88^{0} 53 \mathrm{E}$ ) of Bangladesh. Rice husk was collected from local rice mill, Joypurhat, Bangladesh. It was dried in air dry condition for one day and then burnt 
$750^{\circ} \mathrm{C}$ for 2 hour in furnace, then collect rice husk ash (RHA) which is black in color. Fly ash was collected from thermal power plant of Boropukuria, Dinajpur district of Bangladesh.

\subsection{Preparation of sample}

The RHA, fly ash and clay sample were ground in powder form, dried in air dry and sieving at $250 \mu \mathrm{m}$. Different percentages of rice husk ash and fly ash (5\%, 10\% and 15\%) were thoroughly mixed with clay and a graded addition of water until approximately the optimum moisture content as determined during compaction. The test specimens were rectangular $(75 \mathrm{~mm} \times 20 \mathrm{~mm} \times 15 \mathrm{~mm})$ in size. The specimens were air dried at room temperature for $24 \mathrm{hr}$ and then oven dried at $110^{\circ} \mathrm{C}$ for another $24 \mathrm{hr}$ to remove water content. All the specimens were fired analysis various physical properties of clay followed by heat treatment of $800^{\circ} \mathrm{C}$ to $1100^{\circ} \mathrm{C}$ temperature in an electric furnace for $1 \mathrm{hr}$ under heating rate of $10^{\circ} \mathrm{C} / \mathrm{min}$.

\subsection{Chemical analysis}

The elements were determined by X-ray fluorescence Spectrometer (XRF) method following the procedures of Goto and Tatsumi [10] using Rigaku ZSX Primus XRF machine equipped with an end window $4 . \mathrm{kW} \mathrm{R}^{\mathrm{H}}$-anode $\mathrm{X}$-ray tube.

\subsection{Physical analysis}

Bulk density, water absorption, porosity and specific gravity were determined by boiling water method followed by ASTM C20-00 [11]. Plasticity of clay sample was determined by Atterberg's method. Linear shrinkage was determined by the test sample length after drying at $110^{\circ} \mathrm{C}$ and the sample length after firing at different temperature

To determine mechanical strength different percentages of additives was thoroughly mixed with clay samples and there after molded into some block $(4.5 \mathrm{~cm} \times 4.5 \mathrm{~cm} \times 4.5$ $\mathrm{cm}$ ) in size. The test samples were air-dried at room temperature for $24 \mathrm{hr}$, dried at $110^{\circ} \mathrm{C}$ for another $24 \mathrm{hr}$, then fired at $1050^{\circ} \mathrm{C}$ for $1 \mathrm{hr}$ and cooled to room temperature. Then mechanical strength was determined by using compressive testing machine. Each test piece was centrally positioned between the platens of the testing machine, and the load was gradually increased until failure.

\subsection{Phase analysis}

The phase composition of the clay sample and prepared samples were determined by the XRD analysis of the sample with Bruker X-ray Diffractometer model operating with a $\mathrm{CuK} \alpha$ radiation source $(\mathrm{K} \alpha=1.5406 \AA)$. 


\section{Results and Discussion}

\subsection{Chemical and physical analysis of the raw materials}

The chemical compositions of clay sample, fly ash and rice husk ash (RHA) are shown in Table 1. From table the result shows high silica content of all raw materials. Iron content of $7.83 \%$ in the clay was sufficient to develop a reddish color. The high $\mathrm{K}_{2} \mathrm{O}(3.5 \%)$ content in clay raw material is probably due to the relatively large amount of illite content.

Table 1. Chemical composition of raw materials.

\begin{tabular}{llll}
\hline $\begin{array}{l}\text { Components } \\
(\%)\end{array}$ & Clay & Fly ash & RHA \\
\hline $\mathrm{SiO}_{2}$ & 65.3 & 53.77 & 74.2 \\
$\mathrm{Al}_{2} \mathrm{O}_{3}$ & 20.2 & 29.69 & 2.42 \\
$\mathrm{Fe}_{2} \mathrm{O}_{3}$ & 7.83 & 6.33 & 2.97 \\
$\mathrm{~K}_{2} \mathrm{O}$ & 3.55 & 1.78 & 4.91 \\
$\mathrm{CaO}$ & 0.27 & 3.09 & 2.55 \\
$\mathrm{Na}$ & 0.31 & 0.094 & 0.480 \\
$\mathrm{MgO}$ & 1.1 & 0.582 & 2.17 \\
$\mathrm{TiO}_{2}$ & 0.971 & 2.43 & 0.323 \\
$\mathrm{P}_{2} \mathrm{O}_{5}$ & 0.805 & 0.44 & 7.49 \\
$\mathrm{pH}$ & 6.1 & 7.2 & 8.3 \\
$\mathrm{Specific} \mathrm{gravity}$ & 2.25 & 2.34 & 2.11 \\
\hline
\end{tabular}

Table 2 shows the Atterberg's limit of clay sample that used in the experiment. The plasticity index (13.66) indicates low to medium ranges of plasticity of clay sample. It can be observed the values of liquid limit at about $38 \%$, which are in agreement with the range defined in the literature (30-60\%) to composition used for ceramic production [12].

Table 2. Atterberg's limit of clay.

\begin{tabular}{ll}
\hline Liquid limit (LL) & 38.95 \\
Plastic limit (PL) & 25.29 \\
Plastic index(PI) & 13.66 \\
\hline
\end{tabular}

XRD patterns indicate the clay sample was (Fig. 1) mainly illite type with significant amount of quartz and hematite. It was also reported from Alam et al. [13] that illite is the dominant mineral in the clay fractions of the soils of the archeological sites of Paharpur area, Naogaon district of Bangladesh. 


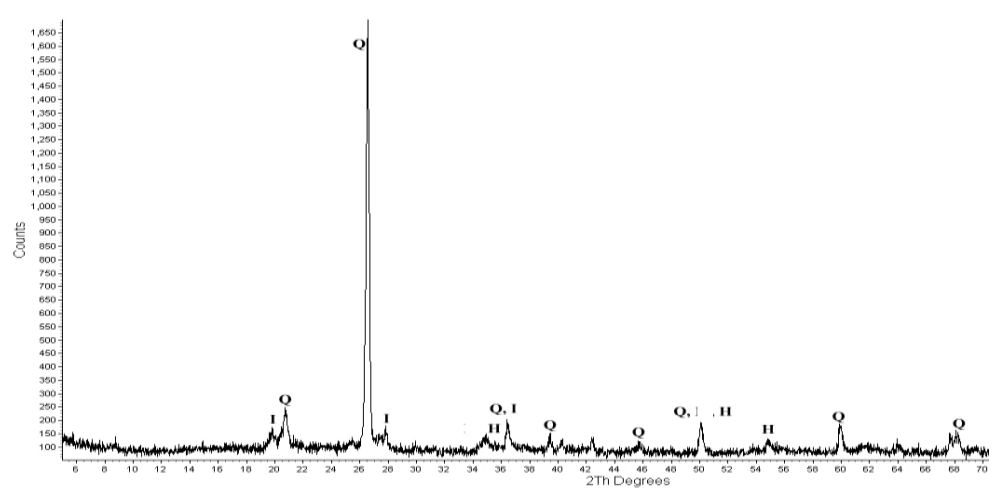

Fig. 1. X-ray diffraction pattern of the clay sample $(\mathrm{Q}=$ quartz, $\mathrm{I}=\mathrm{illite}, \mathrm{H}=$ hematite $)$

\subsection{Physical properties of the prepared samples}

To assess the potential of red clays with additives for industry, primarily physical characteristics were considered. Determination of water absorption, bulk density, porosity and shrinkage are the tools for the degree of maturation or vitrification of a ceramic body. All the specimens were fired analysis various physical properties of clay followed by heat treatment of $800^{\circ} \mathrm{C}$ to $1100^{\circ} \mathrm{C}$ temperature. The optimum firing temperature for all the samples was $1050^{\circ} \mathrm{C}$. Therefore, the properties of prepared samples with additives at $1050^{\circ} \mathrm{C}$ temperature have been analyzed here.

The water absorption of the samples has ranged from $7 \%$ to $11 \%$ where maximum absorption obtained $10.34 \%$ for $15 \%$ RHA and $10.28 \%$ for $15 \%$ fly ash. The lowest values were $7.42 \%$ and $9.29 \%$ for 5\% RHA and fly ash respectively. It can be observed from table an increase in water absorption and porosity for all samples with increasing the percentages of RHA and fly ash. It was also observed from Tonnayopas et al. [9] that the increases in RHA replacement give rise to an increase in the water absorption. It is evident from Table 3 that values of water absorption of all the compositions are within the range of that of wall tiles [14]. No significant variation is observed in bulk density values. The bulk density has ranged within 1.70 to $1.88 \mathrm{gm} / \mathrm{cc}$. The loss of ignition was $0.6-2.0$, loss of ignition is also related to the organic matter content.

Table 3. Physical and mechanical properties of the prepared samples.

\begin{tabular}{llllllll}
\hline Properties & $\begin{array}{l}\text { Clay } \\
\text { (without } \\
\text { additive) }\end{array}$ & $\begin{array}{l}5 \% \\
\text { RHA }\end{array}$ & $\begin{array}{l}10 \% \\
\text { RHA }\end{array}$ & $\begin{array}{l}15 \% \\
\text { RHA }\end{array}$ & $\begin{array}{l}5 \% \\
\text { Fly ash }\end{array}$ & $\begin{array}{l}10 \% \\
\text { Fly ash }\end{array}$ & $\begin{array}{l}15 \% \\
\text { Fly ash }\end{array}$ \\
\hline $\begin{array}{l}\text { Bulk density } \\
\text { gm/cc }\end{array}$ & 1.70 & 1.75 & 1.85 & 1.88 & 1.76 & 1.71 & 1.74 \\
$\begin{array}{l}\text { Apparent } \\
\text { porosity\% }\end{array}$ & 13.8 & 13.32 & 16.17 & 19.46 & 16.42 & 17.56 & 17.98 \\
\hline
\end{tabular}


Table 3 (contd.)

\begin{tabular}{lccccccc}
\hline $\begin{array}{l}\text { Water } \\
\text { absorption\% }\end{array}$ & 7.6 & 7.42 & 8.73 & 10.34 & 9.29 & 9.3 & 10.28 \\
$\begin{array}{l}\text { Loss of } \\
\text { ignition\% }\end{array}$ & 1.64 & 1.98 & 1.37 & 1.06 & 1.6 & 1.23 & 0.65 \\
$\begin{array}{l}\text { Apparent } \\
\text { specific } \\
\text { gravity\% }\end{array}$ & 1.93 & 2.07 & 2.22 & 2.31 & 2.11 & 2.06 & 2.13 \\
\hline
\end{tabular}

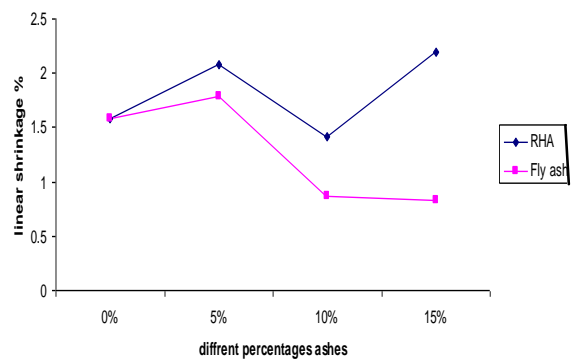

Fig. 2. Variation of linear shrinkage with different ashes.

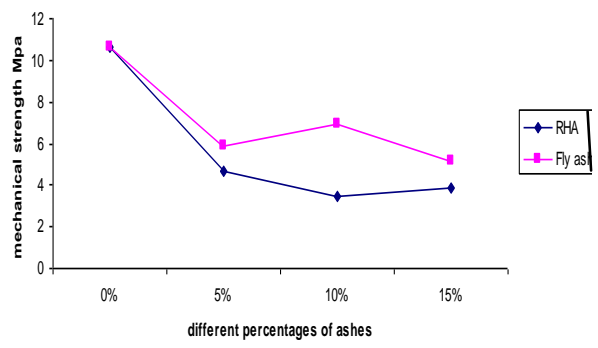

Fig. 3. Mechanical strength variation with different ashes.

It is clear from Fig. 2 that mostly shrinkage decreased with increasing percentage of ashes. It is which may be due to presence of more amorphous silica and which acts as filler material which also explained by Kumar et al. [15]. The value of shrinkage for using different percentages of additives found within the range of $0.83 \%$ to $2.19 \%$. The lowest value found $0.834 \%$ for $15 \%$ fly ash and $1.42 \%$ for $10 \%$ RHA. Firing shrinkage is one of the important criteria representing the quality of the tiles and a lower value of firing shrinkage is always desired to the researchers. Mechanical strength of the samples has ranged with 3.44-10.67 MPa (Fig. 3). The maximum value (10.67 MPa) was found when no additive used. The maximum strength $6.98 \mathrm{MPa}$ for $10 \%$ fly ash was obtained from the test sample. By using different additives, strength may not improve. In fact, increase or decrease in compressive strength as well as other properties depend on the type of soil, type of kiln and also manufacturing process. However by increasing percentages of rice husk ash does not improve the compressive strength of the sample as also reported by ref. [16].There are various parameters that affect the mechanical strength of ceramic materials.

\subsection{Chemical analysis of the prepared samples}

The results of the chemical analyses of the experimental samples are shown in Table 4. It is clear from this analyses that the oxide percentage/constituents present in prepared samples was not varied significantly. This indicates that the combination or mixture of the raw materials have little effect in chemical characteristics. Aluminum oxide content 
slightly decreased for $10 \%$ and $15 \%$ RHA, however increased for $10 \%$ and $15 \%$ fly ash. At alumina contents below $20 \%$ the mixtures were considered as refractory materials, at contents above $20 \%$, as plastic clays [17]. So, the prepared samples mostly are considered as plastic. It will also depend on other physical and mineralogical properties.

Table 4. Chemical compositions of prepared raw materials.

\begin{tabular}{lcccccc}
\hline $\begin{array}{l}\text { Composition } \\
\%\end{array}$ & 5\%RHA & 10\%RHA & $\begin{array}{l}15 \% \text { RHA } \\
\text { 5\%Fly } \\
\text { ash }\end{array}$ & $\begin{array}{l}\text { 10\%Fly } \\
\text { ash }\end{array}$ & $\begin{array}{l}\text { 15\%Fly } \\
\text { ash }\end{array}$ \\
\hline $\mathrm{Na}_{2} \mathrm{O}$ & 0.281 & 0.289 & 0.282 & 0.291 & 0.257 & 0.263 \\
$\mathrm{MgO}$ & 1.06 & 1.11 & 1.12 & 1.008 & 1.076 & 0.991 \\
$\mathrm{Al}_{2} \mathrm{O}_{3}$ & 20.58 & 19.88 & 19.37 & 20.75 & 22.53 & 22.36 \\
$\mathrm{SiO}_{2}$ & 63.64 & 63.62 & 64.43 & 63.27 & 61.48 & 61.85 \\
$\mathrm{P}_{2} \mathrm{O}_{5}$ & 0.237 & 0.404 & 0.555 & 63.27 & 0.115 & 0.132 \\
$\mathrm{~K}_{2} \mathrm{O}$ & 3.88 & 3.86 & 3.79 & 0.098 & 3.61 & 3.47 \\
$\mathrm{CaO}$ & 0.329 & 0.350 & 0.390 & 3.49 & 0.545 & 0.803 \\
$\mathrm{TiO}_{2}$ & 1.05 & 1.01 & 0.947 & 0.438 & 1.12 & 1.24 \\
$\mathrm{Fe}_{2} \mathrm{O}_{3}$ & 8.61 & 8.60 & 8.31 & 1.05 & 8.41 & 8.16 \\
\hline
\end{tabular}

\subsection{Phase analysis of the prepared samples}

The XRD patterns (Figs. 4 and 5) show some differences among various percentages of fly ash and RHA that mixed with clay sample which suggests that phase transformation has take place. Some sharp and intense quartz peak starts to show up for $10 \%$ and $15 \%$ ashes mixture, this may be due to the recrystallisation of amorphous silica to crystalline with temperature and mixture of additives. The XRD pattern of clay with fly ash and rice husk ash heated at $1050^{\circ} \mathrm{C}$ confirms the presence of crystobalite, feldspar and quartz as major phase. Hematite $\left(\mathrm{Fe}_{2} \mathrm{O}_{3}\right)$ phase also observe for both additives. It was also reported by Escalera et al. [18] that illite peaks have disappeared completely at $1050^{\circ} \mathrm{C}$ due to the illite structure breaking down in this range of temperature and Hematite begins to crystallize at $1050^{\circ} \mathrm{C}$.

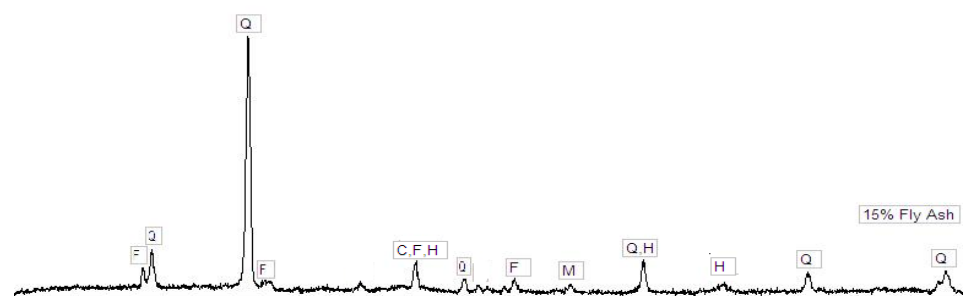



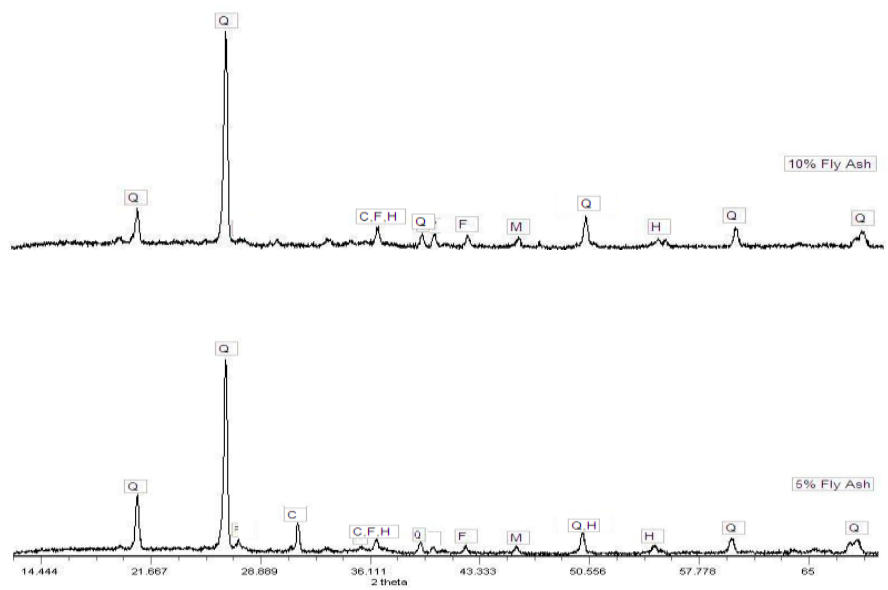

Fig. 4. XRD patterns of prepared samples with different percentages of fly ash at $1050^{\circ} \mathrm{C}$ $(\mathrm{Q}=$ quartz, $\mathrm{C}=$ cristobalite, $\mathrm{F}=$ feldspar, $\mathrm{H}=$ hematite and $\mathrm{M}=$ muscovite) .
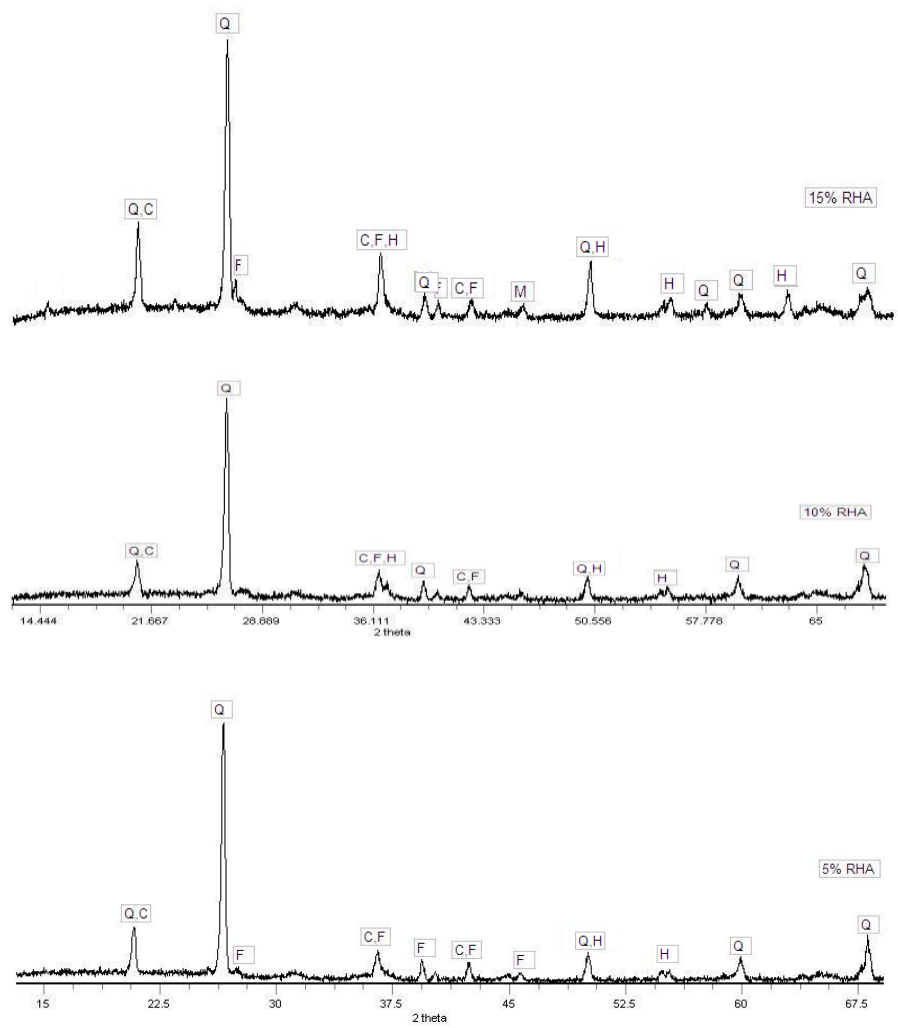

Fig. 5. XRD patterns of prepared samples with different percentages of rice husk ash at $1050^{\circ} \mathrm{C}(\mathrm{Q}=$ quartz, $\mathrm{C}=$ cristobalite, $\mathrm{F}=$ feldspar, $\mathrm{H}=$ hematite and $\mathrm{M}=$ muscovite $)$. 


\section{Conclusion}

The characterization of red clay and effects of different additives on properties of clay sample lead to following conclusions:

- The shrinkage values were low. Low shrinkage indicates that it reduces the risk of defects such as warping and cracking.

- The percentage of water absorption was within 6 to $10 \%$ for different mixture which may be suitable for ceramic and tiles purposes.

- Both fly ash and RHA of $15 \%$ could be used to improve some properties of clay.

- The optimum firing temperature for all the samples was $1050^{\circ} \mathrm{C}$. Thus this red clay deposits could be used to produce a wide range of ceramic and industrial product by taking advantages of low cost and environmental protection.

- After firing the test specimens color were red without glazing, possible use to produce with superior commercial value when compared with other industrial materials.

\section{Acknowledgements}

The authors would like to thank Md. Rakibul Kadir, Engineer, PP and PDC, BCSIR for help in XRD analysis. The authors are also thankful to scientists, technicians and laboratory attendants of the Institute of Mining, Mineralogy and Metallurgy, BCSIR for co-operation during this work.

\section{References}

1. M.A. Rahman, Mater. Struc. 21, 222 (1988). http://dx.doi.org/10.1007/BF02473059

2. D.A. Okongwu, Ceram. Bull. 67 (8), 1409 (1988).

3. E. J. Ibanga and A. D. Ahmed, Pacific J. Sci. Tech. 8 (2), 267 (2007).

4. S. K.Sen and P. S. Agarwal, Silic. Ind. 62 (1/2), 39 (1997).

5. S. K. Das, S. Kumar, K. K. Singh, and P. R. Rao. Proc. RVBIS, IIM. Ghatshila, India, pp. 7-10 (1996).

6. H. M. Sha, and K.N. Maity, Trans. Indian Ceram. Soc. 60 (3), 145 (2001). http://dx.doi.org/10.1080/0371750X.2001.10799989

7. I. O Agbede and M Joel. Am. J. Sci. Ind. Res., 2 (4), 674 (2011).

8. P. K. Mehta, Concrete structure, properties and materials (Prentice -Hall, Eaglewood Cliffs, N. J., 1986).

9. D. Tonnayopas, P. Tekasakul, and S. Jaritgnam, Effect of rice husk ash on characteristics of lightweight clay brick, Technology and Innovation for Sustainable Development Conference, Khon Kaen University, Thailand, 28-29 Jan. 2008, pp 36-39.

10. A. Bero, ASTM, Designation: C 20-00, Standard Test Methods for Apparent Porosity, Water Absorption, Apparent SpecificGravity, and Bulk Density of Burned Refractory Brick andShapes by Boiling Water, Current edition approved April 10, 2000. Published June 2000. Copyright (C) ASTM, 100 Barr Harbor Drive, West Conshohocken, PA 194282959, United States.

11. A. Goto and Y. Tatsum, The Rigaku J. 13 (2), 20 (1996). 
12. H. Baccour, M. Medhioub, F. Jamoussi and T. Mhiri, J. mater. Process. Techn. 209, 2812 (2009). http://dx.doi.org/10.1016/j.jmatprotec.2008.06.055

13. A. K. M. M. Alam, S. Xie, D. K. Saha, and S. Q. Chowdhury, Environ. Geol. 53, 1639 (2008). http://dx.doi.org/10.1007/s00254-007-0771-1

14. A. G. Komar. Building Materials and Component (Mir Publishers, Moscow, 1974) 480 pages.

15. S. Kumar, U. S. Das and K. K. Sing. Sintering studies on fly ash and clay mixes, Fly Ash Utilization for Value Added Products (Eds). B. Chatrerjee. K. K. Simla \& N. G. Goswarni, NML, Jamshedpur (1999) pp. 99-105.

16. O. S. Obam and A. Y. Iorliam. J. Eng. Appl. Sci. 3, 38 (2011).

17. O. O. Ige, I. I. Akomolafe, and L. E. Umoru. Appl. clay sci. 52, 428 (2011). http://dx.doi.org/10.1016/j.clay.2011.03.022

18. E. Escalera, M-L. Antti and M. Odén, Thermal treatment and phase formation in kaolinite and illite based clays from tropical regions of Bolivia. 6th EEIGM International Conference Advanced Materials Research : 7th and 8th November, 2011 EEIGM, Nancy, France. Bristol : IOP Publishing Ltd, 2012. (I O P Conference Series: Materials Science and Engineering; No. $31)$. 